Analitika: Jurnal Magister Psikologi UMA, Vol. 12 (1) Juni (2020)

ISSN: 2085-6601 (Print), ISSN: 2502-4590 (Online)

DOI: http://dx.doi.org/analitika.v11i1.3401

Jurnal Magister Psikologi UMA

Available online http://ojs.uma.ac.id/index.php/analitika

\title{
Pengaruh Stres Kerja terhadap Cyberloafing dengan Kepuasan Kerja Sebagai Variabel Moderator pada Karyawan di Surabaya
}

\section{The Effect of Work Stress toward Cyberloafing with Job Satisfaction as Moderator Variable on Employees in Surabaya}

\author{
Mazzanov Dhira Brata Moffan \& Seger Handoyo* \\ Program Studi Psikologi, Fakultas Psikologi, Universitas Airlangga, Indonesia
}

Diterima: 23 Januari 2020, disetujui: 27 Juni 2020, dipublish: 30 Juni 2020

*Coresponding author: Email: seger.handoyo@psikologi.unair.ac.id

\begin{abstract}
Abstrak
Menghabiskan waktu kerja menggunakan internet yang tidak ada kaitanya dengan pekerjaan merupakan perhatian utama bagi perusahaan. Penggunaan internet yang tidak ada kaitannya dengan pekerjaan saat jam kerja berlangsung disebut dengan cyberloafing. Penelitian ini bertujuan untuk mengetahui apakah kepuasan kerja dapat memoderasi pengaruh stres kerja terhadap cyberloafing pada karyawan di Surabaya. Penelitian ini bertipe penelitian kuantitatif dengan jumlah subjek penelitian sebanyak 174 responden yang tersebar di Surabaya. Alat pengumpulan data berupa general work stress scale, job satisfaction survey, dan skala cyberloafing. Analisis data dilakukan dengan teknik Moderated Regression Analysis. Hasil penelitian menunjukan bahwa stres kerja berpengaruh langsung terhadap cyberloafing. Sedangkan kepuasan kerja tidak memoderasi pengaruh stres kerja terhadap cyberloafing.

Kata kunci: Cyberloafing; Kepuasan Kerja; Stres Kerja
\end{abstract}

\begin{abstract}
Spending work time using the internet that has nothing to do with work is a major concern for companies. Employees are often negligent in their work or forget because of the internet during work hours. Using the internet that has nothing to do with work during work hours is called Cyberloafing. This study aims to determine whether job satisfaction can moderate the effect of work stress on cyberloafing in Surabaya employees. This research type is quantitative with number of research subjects was 174 respondents spread in Surabaya. Data collection tools in the form of general work stress scale, job satisfaction survey, and cyberloafing scale. Data analysis was performed with Moderated Regression Analysis technique. Results showed that work stress has a direct effect on cyberloafing. Meanwhile job satisfaction does not moderated effect of work stress on cyberloafing.
\end{abstract}

Keywords: Cyberloafing; Job Satisfaction; Work Stress

How to Cite: Moffan, M.D.B., \& Seger, H. (2020). Pengaruh Stres Kerja terhadap Cyberloafing dengan Kepuasan Kerja sebagai Variabel Moderator pada Karyawan di Surabaya. Analitika: Jurnal Magister Psikologi UMA, 12 (1): 64 - 72 


\section{PENDAHULUAN}

Menghabiskan waktu kerja menggunakan internet yang tidak ada kaitanya dengan pekerjaan merupakan perhatian utama bagi perusahaan. Penggunaan internet di perusahaan memiliki fungsi awal untuk mempermudah kinerja karyawan dan dapat mempersingkat waktu karyawan dalam mengerjakan tugas. Fasilitas yang diberikan oleh perusahaan yang ditujukan untuk mempermudah pekerjaan dapat juga memberikan dampak buruk bagi perusahaan. Adanya fasilitas perusahaan yang memudahkan dalam penggunaan internet mengakibatkan karyawan cenderung tidak bijak dalam penggunaan internet (Henle, C. A., \& Blanchard, 2008). Karyawan kerap kali lalai dalam pekerjaannya atau melupakan pekerjaannya karena adanya internet saat jam kerja. Penggunaan internet yang tidak ada kaitannya dengan pekerjaan saat jam kerja berlangsung disebut dengan Cyberloafing.

(Van Doorn, 2011) menyatakan bahwa cyberloafing merupakan istilah untuk menyebutkan perilaku karyawan yang menggunakan fasilitas internet melalui perangkat pribadi atau perusahaan untuk kepentingan pribadi selama jam kerja. Banyak sebutan yang digunakan peneliti untuk menyebut fenomena ini sebagai cyberslacking, cyberslouching, junk computing, cyberloafing, dan non-work related computing (Ozler, D., \& Polat, 2012). Penelitian terdahulu yang menjelaskan fenomena cyberloafing di suatu perusahaan melaporkan bahwa rata-rata karyawan menghabiskan waktunya untuk menggunakan internet yang tidak ada hubungannya dengan pekerjaan sekitar satu jam sampai tiga jam per hari saat bekerja (Henle, C. A., \& Blanchard, 2008). Di Indonesia menunjukan karyawan ratarata menghabiskan waktu satu jam per hari untuk mengakses internet untuk kepentingan pribadi (Aldilasari, N., \& Firmanto, 2017). Aktivitas yang dilakukan seperti browsing, facebook atau kaskus (Aldilasari, N., \& Firmanto, 2017).

Cyberloafing mungkin konstruktif ketika membantu untuk karyawan dan organisasi. Namun, itu bisa merusak ketika aktivitas cyberloafing tersebut mencegah karyawan menjadi produktif (Ozler, D., \& Polat, 2012). Banyak peneliti yang berpendapat bahwa perilaku cyberloafing adalah kegiatan pemborosan dan dapat membuka rahasia perusahaan. Cyberloafing dapat menyebabkan pengurangan produktivitas dan penggunaan sumber daya jaringan yang tidak efisien, sehingga menghasilkan perusahaan yang tidak kompetitif (Ozler, D., \& Polat, 2012). Menurut Lara dan Mesa (2011) menambahkan cyberloafing dapat memberikan masalah pada keamanan sistem informasi dan fungsi umum seperti lambatnya bandwidth, terkena spyware (virus komputer), dan penundaan tugas (dalam Ozler, D., \& Polat, 2012). Cyberloafing bisa disebut juga cyberslacking termasuk salah satu bentuk dari deviant workplace behavior yaitu, dimana cyberloafing dianggap sebagai perilaku kontraproduktif yang membuat tingkat kinerja karyawan menurun (Lim, 2002).

Disisi lain, beberapa peneliti lainnya melaporkan hasil yang bertentangan bahwa mereka tidak percaya cyberloafing itu berdampak buruk 
dan bahkan tidak pantas. Dalam penelitian yang dilakukan oleh Vitak, dkk., (2011) terdapat efek positif cyberloafing seperti, penghilang rasa bosan, kelelahan, atau stres, kepuasan kerja atau kreativitas, meningkatkan kesejahteraan, pemulihan dan rekreasi, dan yang membuat karyawan senang. Dalam penelitian lainnya, (Stanton, 2002) menemukan bahwa karyawan yang sering menggunakan internet lebih puas terhadap pekerjaannya daripada yang jarang menggunakan internet. Terdapat juga hubungan yang positif antara manfaat produktivitas internet dengan aktivitas cyberloafing (Blanchard \& Henle, 2008). Cyberloafing berfungsi sebagai "mainan dikantor" untuk menghilangkan stres kerja dan menginspirasi kreativitas karyawan (Ozler, D., \& Polat, 2012).

Terdapat banyak faktor yang menjadi pemicu munculnya cyberloafing salah satunya adalah stres kerja. Stres merupakan hal yang sering muncul dan berhubungan dengan pekerjaan. Stres kerja adalah keadaan tidak nyaman secara psikologis yang dihasilkan atas penilaian subjektif individu mengenai tuntutan yang dirasakan dari tempat kerja melebihi kemampuan individu untuk berhasil memenuhi tuntutan tersebut (De Bruin, 2006). Menurut Lazarus dan Folkman (dalam De Bruin, 2006), ketika banyak karyawan mengalami stres saat bekerja, mereka cenderung mencari beragam cara untuk mengatasi atau mengurangi stres ditempat kerja, hal itu disebut dengan coping. Cyberloafing ini merupakan salah satu varian perilaku coping stres karyawan ditempat kerja (Henle, C. A., \& Blanchard, 2008). Perilaku tersebut merupakan salah satu pelarian karyawan dari stres kerja untuk mengurangi emosi negatif karyawan seperti depresi, keresahan, susah konsentrasi, dan lainlain. Penelitian yang pernah dilakukan oleh Oravec yang berjudul "Constructive approaches to Internet recreation in the workplace" menjelaskan bahwa karyawan melakukan perilaku cyberloafing untuk menurunkan beban stres kerja mereka (Oravec, 2002). Walaupun cyberloafing digunakan oleh karyawan untuk mengurangi stres kerja mereka, tetap saja hal itu tidak dibenarkan. Perusahaan membayar mahal karyawan untuk meningkatkan produktivitas yang didapat. Karyawan yang melakukan cyberloafing bisa dikatakan pergi dari tugas yang seharusnya mereka kerjakan.

Ozler dan Polat (2012), mengatakan bahwa kepuasan kerja termasuk pemicu muncul cyberloafing. Kepuasan kerja merupakan salah satu hal yang sangat penting untuk individu yang bekerja di setiap tingkatan organisasi. Kepuasan kerja adalah perasaaan seseorang terhadap pekerjaannya dan terhadap berbagai macam aspek dari pekerjaan tersebut, sehingga kepuasan kerja berkaitan dengan sejauh mana seseorang menyukai (puas) atau tidak menyukai (tidak puas) dengan pekerjaannya (Spector, 1997). Menurut Spector (1997), Karyawan yang puas dengan pekerjaannya ketika gaji yang ia dapatkan sesuai dengan hasil kerja, kesempatan untuk naik jabatan, atasan yang memusatkan perhatian kepada karyawan, mendapatkan tunjangan tambahan yang adil dan sebanding, penghargaan terhadap hasil kerja, alur birokrasi yang jelas dan beban kerja yang tidak berlebihan, hubungan rekan kerja 
yang menyenangkan dan rukun, pekerjaan itu sendiri, dan kelancaran komunikasi dalam perusahaan terkait tugas dan lainlain.

Penelitian yang dilakukan oleh Woon dan Pee (2004) menjelaskan bahwa tingkat kepuasan kerja karyawan yang tinggi akan berpotensi untuk memunculkan penyalahgunaan internet pada karyawan tersebut. Stanton (2002) menemukan bahwa pelaku penyalahgunaan internet lebih mungkin pada karyawan yang memiliki kepuasan yang tinggi. Penelitian yang dilakukan oleh Celik (2015), menemukan bahwa terdapat hubungan yang positif yang kuat antara kepuasan kerja dengan cyberloafing.

Terdapat juga penelitian yang menemukan hasil yang berbeda dengan penelitian lainnya, menurut Vitak, dkk. (2011), kepuasan yang menurun kemungkinan terlibat dalam kegiatan cyberloafing meningkat. Studi yang dilakukan Mahatankoon, Anandarajan, \& Igbaria (2004), menjelaskan karyawan yang merasa tidak puas dengan pekerjaan mereka, akan lebih sering melakukan aktivitas yang tidak berhubungan dengan pekerjaan salah satunya cyberloafing sehingga menimbulkan efek negatif pada kinerja kerja mereka. Lim \& Teo (2005), menemukan hubungan negatif antara kepuasan kerja dengan cyberloafing, hal ini dikarenakan karyawan merasa upah yang diberikan tidak sesuai dengan tugas yang dikerjakan dan tidak adanya apresiasi serta perhatian dari atasan sehingga mereka melakukan cyberloafing. Dengan adanya hasil-hasil yang berbeda dari beberapa penelitian sebelumnya, bisa jadi bahwa kepuasan kerja bukan merupakan variabel independen karena hubungan kepuasan kerja dengan cyberloafing dianggap belum konsisten dikarenakan banyaknya variasi hasil hubungan sehingga perlu dilakukan penelitian terkait hal tersebut.

Kepuasan kerja diprediksi dapat mempengaruhi pengaruh stres kerja terhadap cyberloafing, dimana dengan kepuasan kerja mampu untuk melemah atau menguatkan pengaruh stres kerja terhadap perilaku cyberloafing yang muncul pada karyawan. Ketika karyawan memiliki tingkat kepuasan tinggi, karyawan akan bercerita kepada atasannya untuk mengekspresikan stres kerja yang mereka rasakan kepada atasan mereka ketimbang melakukan cyberloafing. Hal ini dapat dijelaskan dari aspek kepuasan kerja Spector (1997) karyawan yang merasa puas dengan pekerjaannya karena atasan bersikap mendukung, penuh perhatian, hangat dan bersahabat, memberi pujian atas kinerja yang baik dari bawahan, mendengar pendapat dari bawahan, dan memusatkan perhatian kepada karyawan. Menurut Robbins \& Judge (2013), karyawan yang tidak merasa puas akan lingkungan kerja mereka akan melalukan hal lain, salah satunya cyberloafing. Studi yang dilakukan Mahatankoon, dkk. (2004) menjelaskan karyawan yang yang merasa tidak puas dengan pekerjaan mereka, akan lebih sering melakukan aktivitas yang tidak berhubungan dengan pekerjaan. Sehingga ketika karyawan merasa stres dan tidak puas dengan pekerjaannya, justru akan meningkatkan perilaku cyberloafing itu semakin muncul. Hipotesis yang dihasilkan dari penjelasan diatas tersebut sebagai berikut: 
H0: Kepuasan kerja tidak memoderasi pengaruh stres kerja terhadap cyberloafing pada karyawan di Surabaya. Ha: Kepuasan kerja memoderasi pengaruh stres kerja terhadap cyberloafing pada karyawan di Surabaya.

\section{METODE PENELITIAN}

Penelitian ini menggunakan pendekatan kuantitatif. Terdapat tiga variabel yaitu variabel dependen, variabel independen, dan variabel moderator (Neuman, 2013). Variabel yang digunakan dalam penelitian ini sebagai berikut; Variabel dependen merupakan suatu variabel yang variasinya dapat mempengaruhi variabel lain. Variabel dependen dalam penelitian ini adalah stres kerja; Variabel independen merupakan variabel yang diukur untuk mengetahui besarnya efek atau hubungan variabel lain. Akibat atau konsekuensi tersebut bervariasi mengikuti perubahan variabel dependen. Dalam penelitian ini, variabel independen yang diuji adalah cyberloafing; Variabel moderator adalah sebuah variabel yang dapat mempengaruhi kuat atau lemah hubungan antara satu variabel dengan variabel yang lain. Dalam penelitian ini, variabel moderator penulis adalah kepuasan kerja.

Populasi dalam penelitian ini adalah karyawan kantor yang sudah bekerja selama enam bulan lebih di kota Surabaya. Teknik sampling yang digunakan adalah nonprobability sampling dan jenisnya purposive sampling. Teknik pengumpulan data yang digunakan dalam penelitian ini adalah dengan menggunakan kuisioner berupa pernyataan seperti "Pekerjaan membuat saya sangat tertekan sehingga saya berharap memiliki pekerjaan lain"; "Sedikit kesempatan bagi saya, untuk dipromosikan pada pekerjaan saya"; dan "Saya menggunakan internet untuk keperluan pribadi pada saat jam kerja dengan maksud menjaga jejaring sosial".

Kuisioner berisi pertanyaanpertanyaan yang tertulis yang merupakan alat pengumpul data mengenai konsep dari atribut psikologis atau variabel penelitian (Neuman, 2013). Alat ukur yang digunakan peneliti untuk mengukur stres kerja adalah general work stress scale (GWSS) yang disusun oleh Bruin \& Taylor (2005). Skala ini terdiri dari 9 aitem dan merupakan unidimensi yang berlandasan dari sembilan faktor penyebab stres kerja serta memiliki lima pilihan jawaban dari (1) tidak pernah; (2) jarang; (3) kadangkadang; (4) sering; dan (5) selalu. Selanjutnya, alat ukur dalam penelitian ini untuk mengukur kepuasan kerja adalah job satisfaction survey yang disusun oleh Spector (1997). Alat ukur ini terdiri dari 36 aitem yang berlandasan dari aspek kerja yang dikemukakan oleh Spector (1997) dan memiliki empat pilihan jawaban dari (1) sangat tidak setuju; (2) tidak setuju; (3) setuju; dan (4) sangat setuju. Terakhir, alat ukur yang digunakan untuk mengukur cyberloafing dalam penelitian ini adalah skala cyberloafing yang disusun oleh Doorn (2011). Alat ukur ini terdiri dari 24 aitem dan memiliki dua dimensi utama. Skala cyberloafing memiliki lima pilihan jawaban dari (1) tidak pernah; (2) jarang; (3) kadangkadang; (4) sering; dan (5) selalu.

Teknik analisis yang digunakan dalam penelitian ini dilakukan dengan menggunakan bantuan perangkat lunak IBM SPSS Statistics 22. Untuk melakukan 
analisis data, sesuai dengan tujuannya, peneliti menggunakan uji analisis Regresi MRA (Moderated Regression Analysis). Sebelum melakukan analisis data, peneliti melakukan uji analisis statistik deskriptif, uji asumsi yang termasuk di dalamnya uji normalitas, uji linieritas, uji heterokedesitas, uji multikolinearitas, dan juga dilakukan uji korelasi untuk memperkuat bahwa terdapat hubungan, dan juga menjadi syarat untuk melakukan analisis dengan metode regresi.

\section{HASIL DAN PEMBAHASAN}

Jumlah responden 174 orang dengan rentang usia 18-55 tahun dan diantaranya terdapat 114 responden lakilaki $(65,5 \%)$ dan sisanya 60 responden perempuan $(34,5 \%)$. Mayoritas subjek merupakan lulusan dari S1, yaitu sebanyak 94 responden (54\%). Selanjutnya, lulusan SMA merupakan lulusan terbanyak kedua berjumlah 55 responden (31,6\%). Lulusan S2 menempati urutan ketiga dengan jumlah 14 responden (8\%) dan lulusan diploma berjumlah 11 responden (6,3\%).

Sebaran skor yang diperoleh dengan menggunakan norma stanfive diketahui bahwa dalam penelitan ini mayoritas karyawan bekerja di Surabaya memiliki tingkat stres kerja rendahsedang. Selanjutnya, mayoritas karyawan di Surabaya dalam penelitian ini memiliki tingkat kepuasan kerja sedang. Terakhir, mayoritas karyawan di Surabaya dalam penelitian ini memiliki tingkat melakukan cyberloafing sedang-tinggi. Ketiga variabel memiliki reliabilitas alat ukur dengan koefisen reliabilitas alpha cronbach $>0.9$ yaitu koefisien reliabilitas stres kerja 0.911; koefisien reliabilitas kepuasan kerja 0.904; dan koefisien reliabilitas cyberloafing 0.908 dimana nilai semakin mendekati 1.00 maka akan semakin baik reliabilitas alat ukur tersebut.

Uji asumsi yang pertama yaitu uji normalitas residual menunjukan persebaran data normal yang dilihat dari nilai sig. Kolmogrov-Smirnov dan sig. Shapiro-Wilk yaitu 0.2 dan 0.068 (sig. Kolmogrov-Smirnov > 0.05; sig. ShapiroWilk $>0.05$ ), serta dilihat dari p-plot yang mengikuti garis lurus. Selanjutnya, uji linearitas yang dihasilkan dilihat dari nilai deviation from linearity menunjukan nilai sig. $>0.05$ yang berarti data bersifat linear. Ketiga, uji heterokedastisitas dilakukan dan scatterplot tidak menunjukan pola tertentu sehingga dapat diasumsikan bahwa tidak terjadi gejala heterokedastisitas. Keempat, uji multikoleniaritas menunjukan nilai tolerance $=0.976$ dan VIF $=1.024$ yang berarti tidak terjadi interkorelasi antara variabel independen (tolerance $>0.1 ;$ VIF $<$ 10). Terakhir, uji korelasi pearson menunjukan variabel stres kerja berhubungan positif signifikan dengan variabel cyberlaofing (pearson correlation $=0,277$; sig. $=0.000$ ).

Setelah uji asumsi terpenuhi, uji regresi dilakukan untuk menjawab hipotesis penelitian. Tahapan analisis dalam penelitian adalah uji regresi sederhana antara stres kerja terhadap cyberloafing dan uji regresi interaksi (moderated regression analysis). Hasil uji regresi yang pertama menunjukan bahwa stres kerja berpengaruh positif signifikan terhadap cyberloafing dengan besar pengaruh $7.7 \%$ (sig. $0.000<0.05 ; \mathrm{R}=$ $0.277 ; \mathrm{R}$ square $=0.077 ; \beta=0,648$ ). Selanjutnya, Uji moderated regression 
analysis menghasilkan temuan bahwa kepuasan kerja tidak signifikan memoderasi pengaruh stres kerja terhadap cyberloafing (sig. $0.291>0.05 ; \beta$ $=0.018$ ).

Penelitian ini memiliki hipotesis alternatif yaitu adanya peran moderasi kepuasan kerja pada pengaruh stres kerja terhadap cyberloafing karyawan di Surabaya. Variabel moderator ini yang memprediksi keduanya menjadi berubah arah berdasarkan tingkat kepuasan kerja yang dimiliki seseorang, dengan kata lain jika stres kerja terhadap cyberloafing memiliki arah pengaruh yang positif ketika kepuasan kerja rendah atau tidak ada, maka akan berubah menjadi negatif ketika tingkat kepuasan kerja tinggi.

Analisis pertama dalam pengujian hipotesis menunjukan bukti empiris stres kerja secara signifikan mempengaruhi cyberloafing pada karyawan dengan arah pengaruh yang positif. Arah positif menjelaskan bahwa semakin tinggi stres kerja akan semakin tinggi juga cyberloafing pada karyawan dan sebaliknya ketika semakin rendah stres kerja akan semakin rendah juga cyberloafing pada karyawan. Sesuai dengan penelitian yang dilakukan oleh Civilidag (2017), bahwa stres kerja merupakan salah satu faktor yang mempengaruhi perilaku penyalahgunaan internet pada karyawan, karena dinilai efektif untuk melepaskan diri dari stres kerja. Penelitian lain juga dilakukan oleh Sen, dkk. (2016), dimana terdapat hubungan positif yang signifikan antara stres kerja dengan cyberloafing, hasil analisis tersebut menunjukan semakin tinggi stres kerja karyawan maka semakin tinggi pula cyberloafing pada karyawan terjadi. Sen, dkk. (2016), juga dalam penelitiannya, karyawan yang merasa lelah, terganggu, dan ambiguitas peran dalam pekerjaan mengakibatkan stres pada karyawan sehingga cyberloafing menjadi pilihan mereka untuk mengatasi stres. Blanchard \& Henle (2008), dalam penelitian menemukan pengaruh positif dan signifikan stres kerja terhadap cyberloafing, adanya konflik peran dan ambiguitas peran yang merupakan pemicu stres kerja dapat meyebabkan cyberloafing terjadi pada karyawan. Lazarus \& Folkman yang menjelaskan ketika karyawan mengalami stres saat bekerja, mereka cenderung mencari beragam cara untuk mengatasi atau mengurangi stres ditempat kerja. Salah satu cara untuk mengatasi stres kerja tersebut ialah cyberloafing Blanchard \& Henle (2008).

Analisis selanjutnya menghasilkan temuan bahwa kepuasan kerja tidak signifikan memoderasi pengaruh stres kerja terhadap cyberloafing pada karyawan. Tidak adanya pengaruh tersebut membuat peneliti beranggapan bahwa hasil dari variabel kepuasan kerja mayoritas subjek memiliki kepuasan kerja yang sedang, sehingga hal tersebut dirasa belum kuat untuk memoderasi pengaruh stres kerja terhadap cyberloafing. Menurut Spector (1997), karyawan yang memiliki kepuasan yang sedang merasa keraguan diantara puas dan tidak puas dengan pekerjaan mereka (ambivalen). Sehingga peluang untuk membuktikan moderasi cenderung rendah. Dari rentang usia dalam penelitian ini, mayoritas yang mengisi penelitian ini adalah dari rentang umur 18-35 tahun, yang dimana dari rentang umur tersebut merupakan 
generasi Y menurut Kolnhofer-Derecskei, dkk. (2017). Bencsik \& Machova (2016), menjelaskan bagi generasi $\mathrm{Y}$ yang hidup dengan perkembangan akses teknologi dan informasi, terutama internet yang dimana sudah menjadi budaya global, sehingga hal tersebut berpengaruh terhadap nilai, pandangan, dan tujuan hidup. Karyawan generasi Y juga dinilai mampu mengaplikasikan semua kegiatan dalam satu waktu (multi tasking), seperti bekerja sambil mendengarkan musik, membuka media sosial, browsing menggunakan PC dalam kehidupan bekerja maupun sosial mereka (Bencsik, dkk., 2016). Dalam hal kepuasan kerja, generasi $\mathrm{Y}$ akan membutuhkan waktu yang lama untuk merasa puas dengan pekerjaan mereka, hal ini dikarenakan mereka memiliki beberapa pertimbangan terhadap faktor apa saja yang membuat mereka merasa puas dengan pekerjaan (Oktariani, dkk. 2017). Menurut Brown dkk. (2009), mereka malah tidak terlalu mementingkan mereka merasa puas atau tidak dengan pekerjaannya (dalam Oktariani dkk. 2017).

\section{SIMPULAN}

Berdasarkan analisis yang telah dilakukan pada penelitian ini, dihasilkan bahwa terdapat pengaruh positif yang signifikan antara stres kerja terhadap cyberloafing pada karyawan, yang berarti semakin tinggi stres kerja akan semakin tinggi juga cyberloafing pada karyawan dan begitupun sebaliknya semakin rendah stres kerja akan semakin rendah juga cyberloafing pada karyawan. Sedangkan variabel kepuasan kerja tidak dapat memoderasi pengaruh stres kerja terhadap cyberloafing pada karyawan.
Saran untuk peneliti selanjutnya dapat mempertimbangkan kriteria lama bekerja subjek, karena dalam penelitian ini dirasa masih kurang lama untuk melihat tingkat kepuasan kerja seseorang terhadap pekerjaannya. Saran untuk karyawan diharapkan memiliki kontrol diri yang baik sehingga dapat membatasi diri dalam penggunaan internet agar tidak terjadi penundaan tugas yang diamanatkan perusahaan atau instansi. Saran kepada pimpinan untuk menerapkan program manajemen stres bagi karyawan dan memberikan pelatihan untuk meningkatkan keterampilan manajerial karyawan seperti manajemen waktu, penetapan tujuan, komunikasi dan lain-lain untuk mengurangi stres kerja karyawan.

\section{DAFTAR PUSTAKA}

Aldilasari, N., \& Firmanto, A. (2017). Hubungan self control dan perilaku cyberloafing pada pegawai negri sipil. Jurnal Ilmiah Prikologi Terapan, 19-39.

Bencsik, A., \& Machova, R. (2016). Knowledge sharing problems from the viewpoint of intergeneration management. 4th International Conferenceon Management, Leadership and Governance: ICMLG2016, 42.

Celik, N. (2015). Job satisfaction's impact on cyberloafing: an University example. 10th International Academic Conference, 171181.

Civilidag, A. (2017). A research of cyberloafing relations on job stress and job satisfaction at business life. International Refereed $E$ Journal of Social Sciences, 355-373.

De Bruin, G. P., \& Taylor, N. (2005). Development of the sources of work stress inventory. $35(4)$, 748-765. https://doi.org/https://doi.org/10.1177/ 008124630503500408

De Bruin, G. P. (2006). The dimensionality of the general work stress scale: A hierarchical exploratory factor analysis. SA Journal of Industrial Psychology, 32(4), 68-75. https://doi.org/https://doi.org/10.4102/ sajip.v32i4.250 
Henle, C. A., \& Blanchard, A. L. (2008). The interaction of work stressors and organizational sanctions on cyberloafing. Journal of Managerial Issues, 20(3), 383400.

Kolnhofer-Derecskei, A., Reicher, R. Z., \& Szeghegyi, A. (2017). The $X$ and $Y$ generations' characteristics comparison. 14(8), 107-125.

Lim, V. K. G., \& Teo, T. S. H. (2005). Prevalence, perceived seriousness, justification and regulation of cyberloafing in Singapore: An exploratory study. Information and Management, 42(8), 1081-1093. https://doi.org/https://doi.org/10.1016/ j.im.2004.12.002

Lim, V. K. G. (2002). The IT way of loafing on the job. Journal of Organizational Behavior, 23(5), 675-694. https://doi.org/https://doi.org/10.1002/ job.161

Mahatankoon, P. Anandarajan, M. \& Igbaria, M. (2004). Deveopment of a measure of personal web usage in the workplace. Cyberpsychology and Behavior, 93-104.

Neuman, W. L. (2013). Metode penelitian sosial pendekatan kualitatif dan kuantitatif edisi ketujuh. PT. Indeks.

Oktariani, C. D., Hubeis, A. V. S., \& Sukandar, D. (2017). Kepuasan Kerja Generasi X Dan Generasi Y Terhadap Komitmen Kerja Di Bank Mandiri Palembang. Jurnal Aplikasi Bisnis Dan Manajemen, 3(1), 12-22. https://doi.org/https://doi.org/10.17358 /jabm.3.1.12

Oravec, J. A. (2002). Constructive approaches to Internet recreation in the workplace. Communications of the ACM, 60-63.

Ozler, D., \& Polat, G. (2012). Cyberloafing Phenomenon in Organizations: Determinants and Impacts. International Journal of EBusiness and EGovernment Studies, 4(2), 1-15.

Robbins, S. P., \& Judge, T. A. (2013). Organisational Behavior (15th ed.). Pearson.

Sen, E., Tozlu, E., Atesoglu, H., \& Ozdemir, A. (2016). The effect of work stress on cyberloafing behaviour in hIgher education institusion. Social Science Journal, 523-535.

Spector, P. E. (1997). Job satisfaction: Application, assessment, causes, consequance. Sage.

Stanton, J. M. (2002). Web addict or happy employee? Company Profile of the Frequent Internet User. Communications of the ACM, 45(1), 55-59.
Van Doorn, O. N. (2011). Cyberloafing : A multidimensional construct placed in a theoretical framework. In Van Doorn, O. N. Eindhoven University of Technology The Netherlands.

Vitak, J., Crouse, J., \& LaRose, R. (2011). Personal internet use at work: Understanding cyberslacking. Computers in Human Behavior, 24(6), 2475-2476. https://doi.org/https://doi.org/10.1016/ j.chb.2008.03.008

Woon, I. \& Pee, L. (2004). Behavioral Factors Affecting Internet Abuse in the Workplace - An Empirical Investigation Behavioral Factors Affecting Internet Abuse in the Workplace - An Empirical Investigation. Proceedings of the Third Annual Workshop on HCI Research in MIS, Washington, D.C., 80-84. 